2. Miravitlles M, Soler-Cataluña JJ, Calle M, et al. Spanish COPD Guidelines (GesEPOC): Pharmacological Treatment of Stable COPD. Arch Bronconeumol 2012;48:247-57. http://dx.doi.org/10.1016/j.arbr.2012.05.003

3. Anthonisen NR, Manfreda J, Warren CPW et al. Antibiotic-therapy in exacerbations of chronic obstructive pulmonary disease. Ann Intern Med 1987;106:196-204.

4. Jones P, Harding G, Berry P, Wiklund I, Chen W-H, Leidy N. Development and first validation of the COPD Assessment Test. Eur Respir J 2009;34:648-54. http://dx.doi.org/10.1183/09031936.00102509

5. Jones P, Harding G, Wiklund I, Berry P, Leidy N. Improving the process and outcome of care in COPD: development of a standardised assessment tool. Prim Care Resp $J$ 2009;18:208-15. http://dx.doi.org/10.4104/pcrj.2009.00053

6. Gruffydd-Jones K. GOLD guidelines 2011: what are the implications for primary care? Prim Care Respir J 2012;21(4):437-41. http://dx.doi.org/10.4104/pcrj.2012.00058

7. Hurst JR, Vestbo J, Anzueto $A$, et al. Susceptibility to exacerbation in chronic obstructive pulmonary disease. N Eng J Med 2010;363:1128-38. http://dx.doi.org/10.1056/NEJMoa0909883

8. Hardin M, Silverman EK, Barr RG, et al. COPDGene investigators. The clinical features of the overlap between COPD and asthma. Respir Research 2011;12:127. http://dx.doi.org/10.1186/1465-9921-12-127

Commissioned article; externally peer-reviewed; received 16th September 2012; accepted 30th October 2012; online 16th November 2012

(C) 2012 Primary Care Respiratory Society UK. All rights reserved. J Molina. Prim Care Respir J 2012;21(4):446-448.

http://dx.doi.org/10.4104/pcrj.2012.00099

\title{
PERSPECTIVE
}

\section{How I would manage a man with COPD who is symptomatic and at high risk of an exacerbation: a primary care perspective from Norway}

\author{
*Svein Hoegh Henrichsen ${ }^{1,2}$ \\ ${ }^{1}$ GP, Langbolgen legesenter, 1150-Oslo, Norway \\ 2 Senior Adviser, Norwegian Directorate of Health
}

\section{Clinical scenario}

A 69 year-old man attends for a follow-up appointment two weeks after being hospitalised for an exacerbation of COPD. He is improving, though not yet back to normal. He quit smoking after a previous recent admission with a severe exacerbation. Spirometry last year recorded an $\mathrm{FEV}_{1} / \mathrm{FV}$ ratio of 0.36 and a post-bronchodilator $\mathrm{FEV}_{1}$ of $29 \%$ predicted. He is currently taking a combination long-acting $\beta_{2}$-agonist/inhaled corticosteroid inhaler and a long-acting antimuscarinic.

This is a high-risk patient, who was admitted with an exacerbation two weeks ago and comes for follow-up. Mortality after admission to hospital for a COPD exacerbation is $13 \%$ within 6 months. ${ }^{1}$ He has very severe airway obstruction ( $\mathrm{FEV}_{1} 29 \%$ predicted) and has had more than two exacerbations in the previous year. He thus has very severe COPD and is in the new GOLD category D..$^{2,3}$

\section{Exacerbation in patients with severe COPD}

Exacerbations are commonly caused by infections. There is some evidence that COPD patients using inhaled corticosteroids (ICS) have increased risk of bacterial pneumonia. ${ }^{4}$ We should therefore look for signs of infection - fever, chills, tachycardia, coloured sputum - and also assess other possible causes like allergies, stress, undertreatment or non-adherence, and incorrect inhaler technique. In patients with very severe obstruction we should also check for respiratory failure. This can easily be measured with pulse oximetry in primary care.
In Norway we often use the C-reactive protein (CRP) test - a quick and easy test that can be performed in the office - to look for bacterial infections. CRP is an acute phase protein that rises quickly, reaches a peak on day 3-4, and goes back to normal within a week. ${ }^{5}$ A low CRP $(<50)$ after 3-4 days when most patients come to the office would make pneumonia or other bacterial infections unlikely, and would strengthen a decision to treat the exacerbation with oral prednisolone alone (though guidelines recommend that a patient hospitalised with very severe COPD should always have antibiotics ${ }^{2}$. A high CRP (>100) indicates a bacterial infection and should always lead to a prescription of antibiotics and/or a chest X-ray or an admission to hospital with a suspicion of pneumonia. The interpretation of a CRP value between 50 and 100 depends on the time course and symptoms. In the first three days after the symptoms appear (before CRP reaches its peak) a viral infection might reach values above 50. Later in the course of the disease most of us would suspect pneumonia and treat accordingly.

\footnotetext{
* Correspondence: Dr Svein Hoeegh Henrichsen, Langbolgen legesenter, 1150-Oslo, Norway.

Tel: +47 92018702 Fax: +47 22288810 E-mail: shegh@online.no
} 


\section{Follow-up after an exacerbation}

These patients should be followed-up closely and encouraged to come for an acute appointment even if they have started emergency medication. I would normally review them within a few days if they are not hospitalised, or shortly after discharge as in this case. I would check whether he had followed his self-management plan, and offer a prescription for an emergency supply of antibiotics and systemic steroids to replace the treatment he had taken during this exacerbation.

In order to assess the patient it is important to take a good history, including questions about purulent sputum. It does not take long to fill in a disease-specific health status questionnaire such as the COPD Control Questionnaire ${ }^{6}$ in order to monitor objective improvement from the start of the exacerbation. Then a careful clinical examination should be done, paying attention to the lung sounds and presence of signs of pneumonia or heart failure, and an assessment of his BMI. A check on his oxygen saturation with a pulse oximeter may also be helpful, and a value of $92 \%$ or less indicates that referral for long-term oxygen therapy should be considered. In these patients performing spirometry might make the patient worse in the acute phase. ${ }^{2}$ Two weeks after an exacerbation it might be safe, but rarely gives any valuable information - most probably the $\mathrm{FEV}_{1}$ would be around the same value anyway...

Most patients get better within a couple of weeks, though it might take several months to return to how they felt before the exacerbation, as measured by quality of life questionnaires. ${ }^{7}$ Finally we should think of, and manage, co-morbidities - such as lung cancer, hypertension, heart failure, diabetes, osteoporosis and anxiety/depression.

\section{On-going management}

The patient is already receiving maximal drug treatment, taking a combination of ICS and LABA as well as a long-acting antimuscarinic. Compliance and correct inhalation technique is often poor, and I find it very useful to have the patient demonstrating this at each visit - very often improvements can be made. ${ }^{8}$ One might consider adding roflumilast (a PDE4 inhibitor) if he has a lot of symptoms of cough and mucus. ${ }^{9}$ Roflumilast is a new oral treatment indicated as maintenance therapy for patients with severe COPD associated with symptoms of chronic bronchitis and with a history of frequent exacerbations, ${ }^{10}$ though more research is needed to clarify its place in the management of COPD. ${ }^{11}$

The patient should also be encouraged to do some exercise. If it is available, he might be referred for pulmonary rehabilitation, as studies have shown that rehabilitation following hospitalisation for COPD can reduce readmissions. ${ }^{12,13}$ He has already stopped smoking, and it is important to reinforce and give him credit for this. If this has not been done he should also have a yearly 'flu vaccination and I would consider offering a pneumococcal vaccination.

COPD patients have an increased risk of lung cancer compared to people without COPD. ${ }^{14}$ It is therefore important to consider whether one should do a chest $x$-ray. If the patient had not responded to treatment or if I had found any other unexpected signs I would have sent him for an $\mathrm{x}$-ray.
The prognosis in patients with very severe COPD is not good, ${ }^{15}$ and I would listen to the patient to pick up on his concerns. These patients are often isolated and have a poor quality of life. They may be depressed and scared by the experience of an exacerbation. I might look for an opportunity to discuss end-of-life issues, ${ }^{16}$ especially if I had found signs of respiratory failure.

\section{Handling editor Hilary Pinnock}

Conflicts of interest The author declares that he has no conflicts of interest in relation to this article.

\section{References}

1. Almagro $P, C$ Calbo $E$, de Echagüen $A O$, et al. Mortality After Hospitalization for COPD. Chest 2002;121:1441-8. http://dx.doi.org/10.1378/chest.121.5.1441

2. Global Initiative for Chronic Obstructive Lung Disease (GOLD). Global Strategy for the Diagnosis, Management and Prevention of COPD. Updated December 2011 Available from: http://www.goldcopd.org (Accessed August 2012)

3. Gruffydd-Jones K. GOLD guidelines 2011: what are the implications for primary care? Prim Care Respir J 2012;21(4):437-41. http://dx.doi.org/10.4104/pcri.2012.00058

4. Nannini L, Cates CJ, Lasserson TJ, Poole P. Combined corticosteroid and long-acting beta-agonist in one inhaler versus placebo for chronic obstructive pulmonary disease. Cochrane Database of Systematic Reviews 2007, Issue 4. Art. No.: CD003794. http://dx.doi.org/10.1002/14651858.CD003794.pub3

5. Melbye H, Hvidsten D, Holm A, Nordbø SA, Brox J. The course of C-reactive protein response in untreated upper respiratory tract infection. Br J Gen Pract 2004;54 $653-8$

6. van der Molen T, Willemse BW, Schokker S, et al. Development, validity and responsiveness of the Clinical COPD Questionnaire. Health Qual Life Outcomes 2003; 1:13.

7. Spencer $\mathrm{S}$, Jones PW, Time course of recovery of health status following an infective exacerbation of chronic bronchitis. Thorax 2003;58:589-93.

8. Brocklebank D, Wright J, Cates C. Comparison of the effectiveness of inhaler devices in asthma and chronic obstructive airways disease: a systematic review of the literature. Health Technol Assess 2001;5:1-149.

9. Chong J, Poole P, Leung B, Black PN. Phosphodiesterase 4 inhibitors for chronic obstructive pulmonary disease. Cochrane Database of Systematic Reviews 2011, Issue 5. Art. No.: CD002309. http://dx.doi.org/10.1002/14651858.CD002309.pub3

10. Price $D$, Chisholm A, Ryan D, Crockett $A$, Jones $R$. The use of roflumilast in COPD: a primary care perspective. Prim Care Respir J 2010;19:342-51.

11. National Institute for Health and Clinical Excellence. Roflumilast for the management of severe chronic obstructive pulmonary disease. NICE technology appraisal guidance 244. Available from www.nice.org.uk (accessed October 2012)

12. Puhan MA, Gimeno-Santos $E$, Scharplatz $M$, et al. Pulmonary rehabilitation following exacerbations of chronic obstructive pulmonary disease. Cochrane Database of Systematic Reviews 2011, Issue 10. Art. No.: CD005305. http://dx.doi.org/10.1002/14651858.CD005305.pub3

13. Seymour JM, Moore L, Jolley CJ, et al. Outpatient pulmonary rehabilitation following acute exacerbations of COPD. Thorax 2010;65:423-8.

14. Young RP, Hopkins RJ, Christmas T. COPD prevalence is increased in lung cancer, independent of age, sex and smoking history. Eur Respir J 2009;34:380-6.

15. Connors AF, Dawson NV, Thomas C, et al. Outcomes following acute exacerbation of chronic obstructive lung disease. The SUPPORT investigators. Am J Respir Crit Care Med 1996;154:959-67.

16. Pinnock $H$, Kendall $M$, Murray $S$, et al. Living and dying with severe chronic obstructive pulmonary disease: multi-perspective longitudinal qualitative study. $B M$ 2011;342:d142.

Commissioned article; externally peer-reviewed; received 16th September 2012; accepted 30th October 2012 online 16th November 2012

(C) 2012 Primary Care Respiratory Society UK. All rights reserved. SH Henrichsen. Prim Care Respir J 2012;21(4):448-449

http://dx.doi.org/10.4104/pcrj.2012.00100 